\title{
Occurrence of anti-Toxop/asma gondii antibodies and risk factors associated with infection in equids slaughtered for human consumption in Brazil
}

\author{
Ocorrência de anticorpos anti-Toxoplasma gondii e fatores de risco associados \\ a infecção em equídeos abatidos para consumo humano no Brasil
}

Igor Falco Arruda1,2; Wellington Alves de Freitas3; Kênia de Fátima Carrijo3; Paula Silva da Paz; Marianny Miranda Silva ${ }^{3}$; Adriana Pittella Sudré1; Fabielle Marques-Santos ${ }^{1,2}$; Ana Beatriz Monteiro Fonseca4; Maria Regina Reis Amendoeira²; Patricia Riddell Millar ${ }^{1 *}$ (D)

' Departmento de Microbiologia e Parasitologia, Instituto Biomédico, Universidade Federal Fluminense - UFF, Niterói, RJ, Brasi ${ }^{2}$ Laboratório de Toxoplasmose e outras Protozooses, Instituto Oswaldo Cruz, Fundação Oswaldo Cruz - Fiocruz, Rio de Janeiro, RJ, Brasil ${ }^{3}$ Faculdade de Medicina Veterinária, Universidade Federal de Uberlândia - UFU, Uberlândia, MG, Brasil

${ }^{4}$ Departamento de Estatística, Instituto de Matemática e Estatística, Universidade Federal Fluminense - UFF, Niterói, RJ, Brasil

How to cite: Arruda IF, Freitas WA, Carrijo KF, Paz PS, Silva MM, Sudré AP, et al. Occurrence of anti-Toxoplasma gondii antibodies and risk factors associated with infection in equids slaughtered for human consumption in Brazil. Braz J Vet Parasitol 2020; 29(3): e002320. https://doi.org/10.1590/S1984-29612020058

\begin{abstract}
Toxoplasmosis is a worldwide zoonosis caused by Toxoplasma gondii. Ingestion of raw/undercooked meat is considering an important route of infection. Consumption of meat from equids is common in European and Asian countries and an increase in Brazil has been observed. The aim of this study was to evaluate occurrences of anti-T. gondii antibodies and risk factors relating to infection in equids slaughtered for human consumption in Minas Gerais, Brazil. Blood samples from 192 horses and 208 donkeys were collected in the exsanguination area during the slaughter. Serum samples were subjected to the indirect fluorescent antibody test (IFAT). Association analysis was performed using Pearson's chi-square test ( $\chi 2$ ) or Fisher's exact test, to evaluate risk factors relating to the prevalence of seroreagents. Antibodies against $T$. gondii were found in $13.5 \%$ of the equids, with higher occurrence in horses (18.75\%) than in donkeys (8.65\%). Associations between seropositivity and the following variables were found $(p \leq 0.05)$ : species, animal origin, purpose of rearing and source of water for animal consumption and contact with cats. Farms need to implement preventive measures to control T. gondii infection in these species and avert transmission of the parasite to the human population that will consume their meat.
\end{abstract}

Keywords: Toxoplasmosis, horses, donkeys, serology, Minas Gerais.

\begin{abstract}
Resumo
Toxoplasmose é uma zoonose cosmopolita causada pelo Toxoplasma gondii. A ingestão de carne crua/mal cozida é considerada uma importante forma de infecção. A ingestão de carne de equídeos é comum nos países europeus e asiáticos e, no Brasil, tem sido observado um aumento no consumo. $O$ objetivo deste estudo foi avaliar a ocorrência de anticorpos anti-T.gondii e correlacionar com possíveis fatores de risco relacionados à infecção em equídeos que foram abatidos para consumo humano em Minas Gerais, Brasil. Amostras de sangue de 192 equinos e 208 asininos foram coletadas na área de sangria durante o abate. As amostras de soro foram analisadas pela Reação de Imunofluorescência Indireta (RIFI). A análise estatística foi realizada usando o teste qui-quadrado de Pearson ( $\chi 2$ ) ou o teste exato de Fisher, buscando relacionar possíveis fatores de risco com a prevalência de anticorpos. Anticorpos foram encontrados em $13,5 \%$ dos equídeos, com maior ocorrência em equinos $(18,75 \%)$ do que em asininos $(8,65 \%)$. Foram encontradas associações entre soropositividade e as seguintes variáveis $(p \leq 0,05)$ : espécie, origem animal, finalidade da criação e fonte de água para consumo animal e contato com gatos. Os produtores precisam implementar medidas para controlar a infecção nessas espécies, evitando assim, a transmissão do parasita à população humana que consumirá sua carne.
\end{abstract}

Palavras-chave: Toxoplasmose, equinos, asininos, sorologia, Minas Gerais. 


\section{Introduction}

Toxoplasmosis is a worldwide zoonosis caused by Toxoplasma gondii, a coccidian that can infect all homeothermic animals (Tenter et al., 2000). Felids, including the domestic cat, are definitive hosts and responsible for environmental contamination by releasing oocysts in their feces (Bresciani et al., 2016). Mammals, including humans, and birds are intermediate hosts (Robert-Gangneux \& Dardé, 2012). Infection occurs mainly through ingestion of raw or undercooked meat containing tissue cysts, or food or water contaminated with infective oocysts; or through congenital transmission (Amendoeira, 1995; Tenter et al., 2000; Shapiro et al., 2019).

Horses are resistant to this disease and rarely present clinical signs after T. gondii infection (Dubey \& Desmonts, 1987; Dubey, 2010). Although clinical disease in horses is not proven, symptoms that have been correlated with the presence of antibodies include motor incoordination of the limbs, abortion and excessive irritability (Macruz et al., 1975; Coiro et al., 2012; Santos et al., 2014). Stelzer et al. (2019) have shown low frequencies of anti-T. gondii antibodies in these animals, nevertheless, recent reports have notified occurrences of cases of acquired and congenital toxoplasmosis in countries where horsemeat consumption is common (Elbez-Rubinstein et al., 2009; Pomares et al., 2011). In Brazil, the frequency of anti-T. gondii antibodies in equids ranges from $10 \%$ to $28 \%$. It has been detected in all Brazilian regions and in different animal populations (Gennari et al., 2015; Ribeiro et al., 2016; Moura et al., 2016; Venturi et al., 2017; Guerra et al., 2018; Moreira et al., 2019).

Although there is still little information on the role of donkeys in the epidemiology of toxoplasmosis, findings of anti-T. gondii antibodies in this species have shown that the meat of these animals is a possible source of infection (Machacova et al., 2014). Compared with horses, few studies in Brazil have evaluated exposure of donkeys to T. gondii (Oliveira et al., 2012, 2013; Gennari et al., 2015; Guerra et al., 2018). Some studies have suggested that there is a possibility of transmission through consumption of raw asinine milk, but although DNA of the parasite was detected, the infective capacity of the samples was not proven (Mancianti et al., 2014, Martini et al., 2014).

Brazil is currently the country with the eighth largest volume of exports of equid meat. Some European Union countries (Belgium, Netherlands, Italy and France) and Japan are the main consumers of Brazilian horsemeat (Brasil, 2016). Only three Brazilian slaughterhouses are authorized to export equid meat. They are located in the states of Minas Gerais, Rio Grande do Sul and Paraná (Brasil, 2017). In addition to forming a source of infection for humans, this meat can form the means for transporting the parasite to cats and other captive carnivorous animals (Silva et al., 2001).

The aim of this study was to evaluate occurrences of anti-Toxoplasma gondii antibodies and risk factors relating to infection in equids (horses and donkeys) that were slaughtered for human consumption in a slaughterhouse located in the Triângulo Mineiro and Alto Parnaíba mesoregion, Minas Gerais, Brazil.

\section{Materials and Methods}

\section{Population and region studied}

This study was conducted on equids that were slaughtered for human consumption in a slaughterhouse that is licensed for exports by the Federal Sanitary Inspection Service, and which is located in the Triângulo Mineiro and Alto Paranaíba mesoregion, Minas Gerais, Brazil. In this study, the sample calculation took into account the total herd of equidae raised in Brazil and the expected frequency of $50 \%$ for infection by T. gondii in these animals. In order to achieve $95 \%$ confidence level, it was necessary the inclusion of 384 animals. As some sample losses could occur in the process, 400 animals were included. The serum samples collected for this study were obtained from equids in six Brazilian municipalities: two in the state of Bahia, three in the state of Goiás and one in the state of Piauí, as indicated in Figure 1. The animal's owners agreed to participate in the study after being informed of the research objectives, the confidentiality of their identities and their right to refuse to participate at any time. All of the slaughtered animals were destined for external consumer markets in European Union countries and China.

This study was approved by the Ethics Committee for Animal Use of the Laboratory Animal Center (CEUA/NAL) of the Federal Fluminense University, in February 2013 (registration no. 20/13).

\section{Sample collection}

Blood samples were collected in the exsanguination area, in $10 \mathrm{~mL}$ tubes without anticoagulant. The samples were left at room temperature until clot formation. The clot was then removed and the tubes were centrifuged (Excelsa Baby II centrifuge, Fanem ${ }^{\circledR}$ ) at $1000 \mathrm{~g}$ for 10 minutes, for serum separation. The serum samples were then transferred to sterile vials and were stored at $-20^{\circ} \mathrm{C}$ until the time of laboratory analysis. 


\section{Legend}

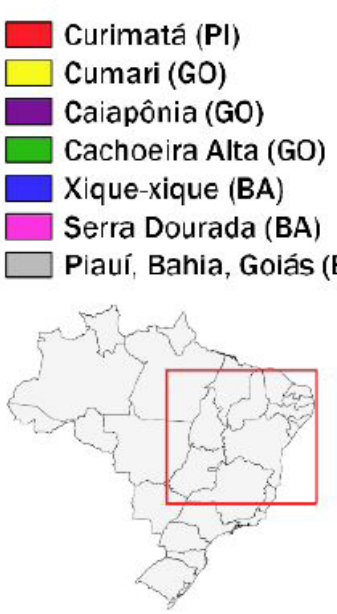

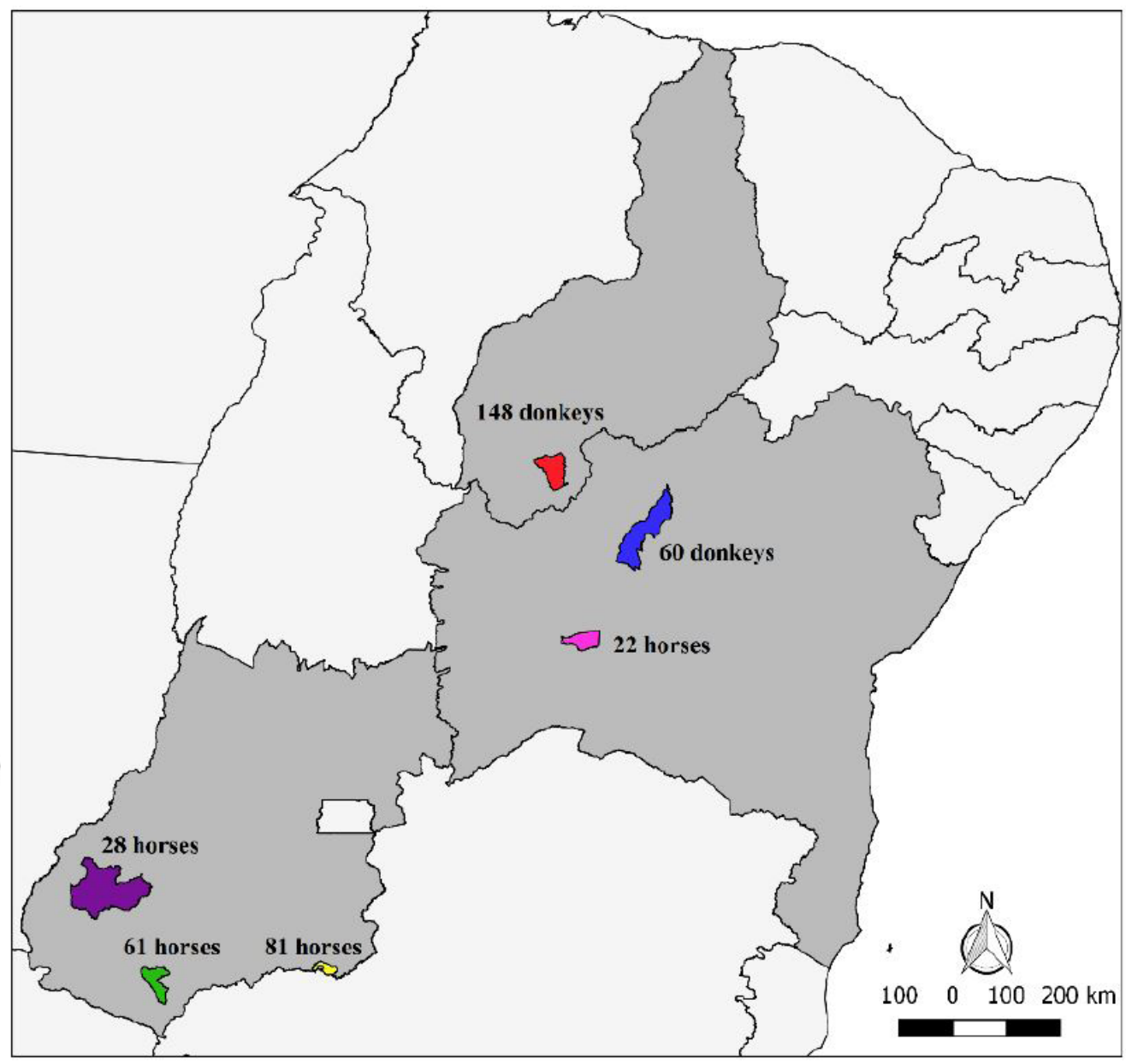

Figure 1. Distribution of equids subjected to detection of anti-Toxoplasma gondii IgG by IFAT from three Brazilian states.

\section{Epidemiological questionnaire}

The farm owners and/or abattoir technical manager answered an epidemiological questionnaire regarding variables such as sex, species, animal origin, diet, contact with cats and rodents, purpose of the animals and origin of water offered to the animals.

\section{Laboratory analysis}

Analyses to detect anti-T. gondii IgG antibodies were performed at the Laboratory for Toxoplasmosis and Other Protozoan Diseases (LabTOXO) of the Oswaldo Cruz Institute (IOC), Fiocruz. Samples were analyzed by means of the indirect immunofluorescent antibody test (IFAT), which was performed as described by Camargo (1964) and in accordance with the protocol established at LabTOXO. Tachyzoites of the RH strain of $T$. gondii that were maintained in Swiss Webster mice were used as the antigen. Positive and negative controls that had previously been tested, and which were stored at the serum bank of LabTOXO, were also used. The commercial conjugate anti-horse IgG FITC (Sigma-Aldrich ${ }^{\circledR}$ ) was used in all reactions, at a dilution of 1:75 in Evan's Blue. Samples were considered positive when formation of the antigen-antibody-fluorescein conjugate complex was observed at a dilution of 1:64 or greater, thus showing total fluorescence of the tachyzoite surface.

\section{Statistical analysis}

The serological results and epidemiological variables were analyzed using the GraphPad Prism 7 statistical software. Associations between two categorical variables were determined using Pearson's chi-square test $(\chi 2)$ or Fisher's exact test, with a significance level of $5 \%$. In order to evaluate the impact among variables, odds ratio (OR) values were described with their respective $95 \%$ confidence interval $(\mathrm{Cl})$. 


\section{Results}

A total of 400 animals (192 horses and 208 donkeys) with an average age of eight years, from different Brazilian states, were included in this study. Presence of anti-T. gondii antibodies was observed in 13.5\% (54/400) of the samples. A positive result at a dilution of 1:64 was observed in 48 samples, while the remaining six were positive at a dilution of 1:256. A higher frequency of antibodies was observed in horses (18.75\%) than in donkeys (8.65\%), and this finding was statistically significant (Table 1). Horses were twice as likely to have anti-T. gondii antibodies as donkeys (OR: 2.4359; 95\% Cl: 1.3313-4.4569). The animals in the state of Goiás had the highest occurrences (Caiapônia, 28.57\%; Cachoeira Alta, 26.23\%; and Cumari, 14.81\%), whereas no occurrence was observed in the animals in the state of Bahia $(p=0.01)$.

Table 1. Risk factor associated with seroprevalence of Toxoplasma gondii infection in equids slaughtered in Minas Gerais. Brazil.

\begin{tabular}{|c|c|c|c|c|}
\hline Variable & $\mathbf{N}^{\circ}$ & $\%$ IFAT & $p$ Value & OR (Cl 95\%) \\
\hline \multicolumn{5}{|l|}{ Speciest } \\
\hline Donkeys & 208 & $8.65 \%$ & 0.005 & $2.4359(1.3313-4.4569)$ \\
\hline Horses & 192 & $18.75 \%$ & & \\
\hline \multicolumn{5}{|l|}{ Sex } \\
\hline Female & 209 & $15.79 \%$ & 0.209 & $0.659(0.367-1.184)$ \\
\hline Male & 191 & $10.99 \%$ & & \\
\hline \multicolumn{5}{|l|}{ Ration consumption } \\
\hline No & 383 & $12.79 \%$ & 0.064 & $2.84(0.959-8.409)$ \\
\hline Yes & 17 & $29.41 \%$ & & \\
\hline \multicolumn{5}{|l|}{ Presence of cats ${ }^{\dagger}$} \\
\hline No & 111 & $21.62 \%$ & 0.005 & $0.420(0.233-0.757)$ \\
\hline Yes & 289 & $10.38 \%$ & & \\
\hline \multicolumn{5}{|l|}{ Presence of rodents } \\
\hline No & 22 & $0.00 \%$ & 0.056 & $1.167(1.120-1.216)$ \\
\hline Yes & 378 & $14.29 \%$ & & \\
\hline \multicolumn{5}{|l|}{ Municipality† } \\
\hline Cachoeira Alta (GO) & 61 & $26.23 \%$ & 0.010 & Undefined \\
\hline Caiapônia (GO) & 28 & $28.57 \%$ & & \\
\hline Cumari (GO) & 81 & $14.81 \%$ & & \\
\hline Curimatá (PI) & 148 & $12.16 \%$ & & \\
\hline Serra Dourada (BA) & 22 & $0.00 \%$ & & \\
\hline Xique Xique (BA) & 60 & $0.00 \%$ & & \\
\hline \multicolumn{5}{|l|}{ Water sourcet } \\
\hline Well & 251 & $9.56 \%$ & 0.004 & $0.4194(0.2346-0.7496)$ \\
\hline Riverside & 89 & $26.97 \%$ & 0.0001 & 3.4585 (1.8966-6.3064) \\
\hline Stream & 169 & $11.83 \%$ & 0.4928 & $0.7777(0.4303-1.4057)$ \\
\hline Weir & 148 & $12.16 \%$ & 0.6537 & $0.8308(0.4531-1.5232)$ \\
\hline Cistern & 72 & $12.50 \%$ & 0.9332 & $0.8984(0.4176-1.9326)$ \\
\hline \multicolumn{5}{|l|}{ Animal purposet } \\
\hline Meat & 132 & $22.73 \%$ & 0.0002 & $2.9902(1.6669-5.3642)$ \\
\hline Milk & 245 & $8.98 \%$ & 0.0010 & $0.3792(0.2111-0.6812)$ \\
\hline Sport & 22 & $0.00 \%$ & 0.0560 & Undefined \\
\hline Others & 95 & $11.58 \%$ & 0.6486 & $0.7979(0.3937-1.6170)$ \\
\hline Not informed & 113 & $6.19 \%$ & 0.0117 & $0.3372(0.1476-0.7705)$ \\
\hline
\end{tabular}

OR: Odds ratio; $\mathrm{Cl}$ : Confidence Interval; IFAT: indirect immunofluorescent antibody test; №: animals' number. † $\mathrm{p}<0.05$. 
Regarding the purpose of rearing, independent analysis of the categories revealed that animals raised for meat production were almost three times more likely to have anti-T. gondii antibodies (OR: 2.9902; 95\% Cl: 1.6669-5.3642). These animals had higher occurrence of anti-T. gondii antibodies (22.73\%). Consumption of water from running sources, such as at riversides, increased the likelihood of presenting antibodies against $T$. gondii threefold among equids (OR: $3.4585 ; 95 \% \mathrm{Cl}: 1.8966-6.3064)$. Animals that consumed this type of water presented higher occurrence of infection (26.97\%) than animals that consumed water from other sources $(p=0.00005)$.

Unexpectedly, the frequency of anti- $T$. gondii antibodies was proportionally higher in horses without contact with cats $(p=0.005)$. However, 55.6\% (30/54) of the seropositive equids lived in establishment with cats. On the other hand, equids on farms with absence of rodents did not show any exposure to this protozoon ( $0 \%)$. In contrast, $14.29 \%$ of the animals that had contact with rodents were seropositive $(p=0.056)$.

There was no statistically significant association between serological positivity and sex and diet $(p>0.05)$ (Table 1).

\section{Discussion}

The present study revealed that equids slaughtered for human consumption in the Triângulo Mineiro region had earlier been exposed to T. gondii. There are no data about the seroprevalence of $T$. gondii infection in equids slaughtered in the Triângulo Mineiro and Alto Paranaíba mesoregion, although there are some records of infection in horses in this region (Naves et al., 2005).

The prevalence of $13.5 \%$ of anti-Toxoplasma gondii IgG antibodies observed in our study can be considered low, however low frequencies have also been detected in horse and donkey populations slaughtered for human consumption in other Brazilian regions. Horses slaughtered in the state of Paraná were found with seropositivity of $11.6 \%$ for T. gondii, these animals are coming from the states of Paraná, Minas Gerais, Rio de Janeiro, Goiás, Mato Grosso and Mato Grosso do Sul (Evers et al., 2013). Also, the prevalence of $14.4 \%$ of antibodies against $T$. gondii in animals from the state of Alagoas was reported by Valença et al. (2015). Otherwise, in the state of Pernambuco detected anti-T. gondii antibodies in $12.5 \%$ of the analyzed animals (Guerra et al., 2018). In Romania and China higher prevalences have been reported (Pastiu et al., 2015; Yang et al., 2013). Despite the low frequency of seropositive animals detected in this study, the occurrence of animals exposed to the protozoan suggests the possibility of parasite transmission to humans through the consumption of its meat. The diagnosis of equids with infection by $T$. gondii is difficult, since most are asymptomatic and naturally resistant to clinical toxoplasmosis. In addition, parasitism by $T$. gondii is not detected in the slaughter line. Thus, the management of these animals should be more appropriate for meat production.

Analyzing risk factors associated with infection in equids slaughtered for human consumption it is noted that, in our study, seropositivity to $T$. gondii was not associated with sex or diet. The animal gender did not affect the rate of positive. This data is similar to other study that observed that equids of both genders were exposed to the same risk factors (Alvarado-Esquivel et al., 2015). All the animals had been grazing on pasture and, among those that had received supplementary feed, consumption of feed doubled the likelihood of presenting antibodies against $T$. gondii, although this was not a statistically significant association, it is possible that cats or other mechanical carriers of oocysts, like rodents, were able to access the places where animal feed was stored, thereby contaminating it. Although ration consumption was not evaluated as possible risk factors in the present study, these have already been identified as factors associated with infection among horses (Alvarado-Esquivel et al., 2015).

There was also no statistical association between serological positivity and the presence of rodents on the farms. However, no seropositive animals were detected on farms without rodents. According to Dubey \& Frenkel (1998), rodents may act as an important source of $T$. gondii tissue cysts for dogs, pigs and, especially, cats. In this regard, the presence of rodents on farms where equids were being reared may have been attractive for felids. In turn, after becoming infected through predatory action, these felids may have contributed towards dispersion of $T$. gondii in the environment through their contaminated feces. Actions and practices aimed towards controlling these small mammals on farms should be encouraged, in order to reduce the risk of parasite transmission.

When we analyzed the species, we can see that the frequency of antibodies observed in this study was higher in horses than in donkeys, which is statistically significant. García-Bocanegra et al. (2012) reported similar results, however, it did not occur in other locations, where mules have statistically greater seropositivity than horses (Gennari et al., 2015). There is no evidence of difference in sensitivity to T. gondii infection among equid species. Thus, the difference between the species that was observed in the present study may be related to their municipality of origin. The seropositive horses were all from Cachoeira Alta (Goiás), Caiapônia (Goiás) and Cumari (Goiás), while 
the seropositive donkeys were all from Curimatá (Piauí). In this study, no occurrences of $T$. gondii infection were detected in equids in municipalities in the state of Bahia, whereas the animals in the state of Goiás presented high frequencies of specific antibodies to the parasite. This difference can be explained, for example, in terms of differences in climatic conditions, since the climate of certain regions can often favor or hinder sporulation of T. gondii oocysts and consequently contamination of food, water and soil (Guerra et al., 2018).

The disparity of results found in the literature is probably due to differences in the following: serological techniques, interpretations, cutoff points, animal populations, geographical conditions, contact with cats and management conditions. These differences have made it difficult to compare studies (Camossi et al., 2010; García-Bocanegra et al., 2012; Papini et al., 2015). Moreover, Oliveira et al. (2012) and Papini et al. (2015) pointed out that there is no gold-standard technique for making the diagnosis of infection in equids.

Another risk factor for T. gondii infection in horses that was studied was the presence of cats in the farms. The contact with felids, especially domestic cats, is one of the main risk factors for acquisition of $T$. gondii infection among herbivorous animals. The importance of close contact between young cats and equids is consistent with the biology of the disease, as young cats are primarily responsible for the shedding of oocysts and the feces of felids can ensure contamination of pasture grass and water that are intended for animal consumption. Equids and other herbivore intermediate hosts of $T$. gondii, such as ruminants, can only become infected by ingestion of food and water contaminated with sporulated $T$. gondii oocysts from felids or by congenital transmission. Thus, the presence of felids on the properties is a fundamental link between these animals and the protozoan. However, in the present study, the greatest occurrence of $T$. gondii infection was among animals that, according to their owners and/or the abattoir technical manager, had not come into contact with cats. This probably constitutes a source of bias in our study, since the difficulty of assessing the real presence of cats in shelters or even fields where equids are kept.

Alike the the present research, Oliveira et al. (2012) also studied animals in Bahia and found that the sources of running water destined for consumption by equids were a risk factor for infection. In fact, water consumption on the riverside, a place also frequented by cats, is an ideal environment for sporulation of oocysts. It is important to note that felids are dispersal agents for T. gondii in the environment. Farming is considered to be an important risk factor for $T$. gondii infection in horses, because the activity keeps these animals close to a potentially contaminated environment.

In our study the age was not evaluated. Age was not a factor associated with infection in horses. In other species studies have shown that age could be is a risk factor, but this generally does not occur with equids (Munhoz et al., 2019).

The prevalence of anti-T. gondii antibodies described in this study (13.5\%) shows the circulation of the parasite in the equine population in Brazil. This result is important in the scope of public health, because, although Brazilians are in the habit of eating equid meat, the country stands out in the export of this product. Moreover, since slaughtering of equids in Brazil mainly occurs as a way of discarding animals previously used for other purposes, their management may not be as appropriate as that applied to other production animals, as pointed out by Evers et al. (2012). Therefore, farms with a more technological approach to horse management, which tend to have better hygiene and sanitary protection practices, will be more able to prevent the spread of certain diseases in horses, including T. gondii infection.

\section{Acknowledgements}

The authors thank the Coordenação de Aperfeiçoamento de Pessoal de Nível Superior (CAPES) for financial support.

\section{References}

Alvarado-Esquivel C, Alvarado-Esquivel D, Dubey JP. Prevalence of Toxoplasma gondii antibodies in domestic donkeys (Equus asinus) in Durango, Mexico slaughtered for human consumption. BMC Vet Res 2015; 11(1): 6. http://dx.doi.org/10.1186/s12917015-0325-9. PMid:25595816.

Amendoeira MRR. Mecanismos de transmissão da toxoplasmose. An Acad Nac Med 1995; 155(4): 224-225.

Brasil. Ministério da Agricultura, Pecuária e Abastecimento. Equídeos [online]. Brasília: MAPA; 2016 [cited 2020 Feb 12]. Available from: http://www.agricultura.gov.br/animal/especies/equideos 
Brasil. Ministério da Agricultura, Pecuária e Abastecimento. Relação de Produtos Autorizados para os Estabelecimentos Brasileiros Exportarem por País [online]. Brasília: MAPA; 2017 [cited 2020 Feb 12]. Available from: ttp://bi.agricultura.gov.br/reports/ rwservlet?sigsif_cons\&prod_aut_estab_bra_exp_pais.rdf\&p_id_pais=\&p_id_mercado_comum=\&p_id_area=1\&p_id_produto=73\&p_ serial=63456746\&paramform=no

Bresciani KDS, Galvão ALB, Vasconcellos AL, Santos TR, Kaneto CN, Viol MA, et al. Epidemiological aspects of feline toxoplasmosis. Arch Vet Sci 2016; 21(2): 1-8. http://dx.doi.org/10.5380/avs.v21i2.39997.

Camargo ME. Improved technique of indirect immunofluorescence for serological diagnosis of toxoplasmosis. Rev Inst Med Trop São Paulo 1964; 6(3): 117-118. PMid:14177810.

Camossi LG, Silva AV, Langoni H. Inquérito sorológico para toxoplasmose em equinos na região de Botucatu-SP. Arq Bras Med Vet Zootec 2010; 6(2): 484-488. http://dx.doi.org/10.1590/S0102-09352010000200032.

Coiro CJ, Langoni $\mathrm{H}$, da Silva R. Epidemiologial aspects in the Leptospira spp. and Toxoplasma gondii infection in horses from Botucatu, São Paulo, Brazil. J Equine Vet Sci 2012; 32(10): 620-623. http://dx.doi.org/10.1016/j.jevs.2012.02.008.

Dubey JP, Desmonts G. Serological responses of equids fed Toxoplasma gondii oocysts. Equine Vet J 1987; 19(4): 337-339. http:// dx.doi.org/10.1111/j.2042-3306.1987.tb01426.x. PMid:3622463.

Dubey JP, Frenkel JK. Toxoplasmosis of rats: a review, with considerations of their value as an animal model and their possible role in epidemiology. Vet Parasito/ 1998; 77(1): 1-32. http://dx.doi.org/10.1016/S0304-4017(97)00227-6. PMid:9652380.

Dubey JP. Toxoplasmosis in Horses (Equus caballus). In: Dubey JP, editor. Toxoplasmosis of animals and humans. 2nd ed. Florida: CCR Press: 2010. p. 177-178.

Elbez-Rubinstein A, Ajzenberg D, Dardé ML, Cohen R, Dumètre A, Yera H, et al. Congenital toxoplasmosis and reinfection during pregnancy: case report, strain characterization, experimental model of reinfection, and review. J Infect Dis 2009; 199(2): 280-285. http://dx.doi.org/10.1086/595793. PMid:19032062.

Evers F, Garcia JL, Navarro IT, Freitas JC, Bonesi GL, Benitez AN, et al. Zoonosis of public health interest in slaughtered Brazilian equidae. Semina: Ciênc Agrár 2012;33(2 Supl2): 3223-3232. http://dx.doi.org/10.5433/1679-0359.2012v33Supl2p3223.

Evers F, Garcia JL, Navarro IT, Zulpo DL, Nino BSL, Ewald MPC, et al. Diagnosis and isolation of Toxoplasma gondii in horses from Brazilian slaughterhouses Braz. J Vet Parasitol 2013; 22(1): 58-63. PMid:23538498.

García-Bocanegra I, Cabezón O, Arenas-Montes A, Carbonero A, DubeyJP, Perea A, et al. Seroprevalence of Toxoplasma gondii in equids from Southern Spain. Parasitol Int 2012; 61(3): 421-424. http://dx.doi.org/10.1016/j.parint.2012.02.003. PMid:22366344.

Gennari SM, Esmerini PO, Lopes MG, Soares HS, Vitaliano SN, Cabral AD, et al. Occurrence of antibodies against Toxoplasma gondii and its isolation and genotyping in donkeys, mules and horses in Brazil. Vet Parasito/ 2015; 209(1-2): 129-132. http://dx.doi. org/10.1016/j.vetpar.2015.01.023. PMid:25747488.

Guerra NR, Almeida JC, Silva EL, Silva EM, Santos JAM, Lepold R, et al. Soroprevalência de Toxoplasma gondii em equídeos do Nordeste do Brasil. Pesq Vet Bras 2018; 38(3): 400-406. http://dx.doi.org/10.1590/1678-5150-pvb-5143.

Machacova T, Bartova E, Di Loria A, Sedlak K, Mariani U, Fusco G, et al. Seroprevalence of Toxoplasma gondii in donkeys (Equus asinus) in Italy. J Vet Med Sci 2014; 76(2): 265-267. http://dx.doi.org/10.1292/jvms.13-0352. PMid:24107428.

Macruz R, Lenci O, Ishizuka MM, Miguel O, Cunha RAF. Toxoplasmose em equinos PSI. Estudo sorológico. Rev Fac Med Vet Zootec Univ S Paulo 1975; 12(1): 277-282. http://dx.doi.org/10.11606/issn.2318-3659.v12i1p277-282.

Mancianti F, Nardoni S, Papini R, Mugnaini L, Martini M, Altomonte I, et al. Detection and genotyping of Toxoplasma gondii DNA in the blood and milk of naturally infected donkeys (Equus asinus). Parasit Vectors 2014; 7(1): 165. http://dx.doi.org/10.1186/17563305-7-165. PMid:24708691.

Martini M, Altomonte I, Mancianti F, Nardoni S, Mugnaini L, Salari F. A preliminary study on the quality and safety of milk in donkeys positive for Toxoplasma gondii. Animal 2014; 8(12): 1996-1998. http://dx.doi.org/10.1017/S1751731114001980. PMid:25118707.

Moreira TR, Sarturi C, Stelmachtchuk FN, Andersson E, Norlander E, Oliveira FLC, et al. Prevalence of antibodies against Toxoplasma gondii and Neospora spp. in equids of Western Pará, Brazil. Acta Trop 2019; 189: 39-45. http://dx.doi.org/10.1016/j. actatropica.2018.09.023. PMid:30267659.

Moura AB, Matiello JP, Silva MO, de Souza AP, Sartor AA. Antibodies against Toxoplasma gondii in horses from the coastal and mountain mesoregions of the state of Santa Catarina, Brazil. Semina: Ciênc Agrár 2016; 37(1): 203-212. http://dx.doi. org/10.5433/1679-0359.2016v37n1p203.

Munhoz AD, Souza MA, Costa SCL, Freitas JS, Silva AND, Lacerda LC, et al. Factors associated with the distribution of natural Toxoplasma gondii infection among equids in Northeastern Brazil. Braz J Vet Parasitol 2019; 28(2): 283-290.

Naves CS, Ferreira FA, Carvalho FSR, Costa GHN. Soroprevalência da toxoplasmose em equinos da raça mangalarga marchador no município de Uberlândia, Minas Gerais. Vet Not 2005; 11(1): 45-52. 
Oliveira E, Albuquerque PPF, Souza OL No, Faria EB, Pinheiro JW Jr, Mota RA. Occurrence of antibodies to Toxoplasma gondii in mules and donkeys in the Northeast of Brazil.J Parasito/ 2013; 99(2): 343-345. http://dx.doi.org/10.1645/GE-3210.1. PMid:22924911.

Oliveira RB Fo, Malta KC, Oliveira JMB, Albuquerque PPF, Mota RA, Santana VLA, et al. Situação epidemiológica da infecção por Toxoplasma gondii em equídeos na microrregião do Brejo Paraibano. Pesq Vet Bras 2012; 32(10): 995-1000. http://dx.doi. org/10.1590/S0100-736X2012001000008.

Papini RA, Buzzone G, Nardoni S, Rocchigiani G, Mancianti F. Seroprevalence and genotyping of Toxoplasma gondii in horses slaughtered for human consumption in Italy.J Equine Vet Sci 2015; 35(8): 657-661. http://dx.doi.org/10.1016/j.jevs.2015.06.012.

Paştiu Al, Gyorke A, Kalmár Z, Bolfã P, Rosenthal BM, Oltean M, et al. Toxoplasma gondii in horse meat intended for human consumption in Romania. Vet Parasito/ 2015; 212(3-4): 393-395. http://dx.doi.org/10.1016/j.vetpar.2015.07.024. PMid:26238654.

Pomares C, Ajzenberg D, Bornard L, Bernardin G, Hasseine L, Dardé ML, et al. Toxoplasmosis and horse meat, France. Emerg Infect Dis 2011; 17(7): 1327-1328. http://dx.doi.org/10.3201/eid1707.101642. PMid:21762609.

Ribeiro MJM, Rosa MHF, Bruhn FRP, Garcia AM, Rocha CMBM, Guimarães AM. Seroepidemiology of Sarcocystis neurona, Toxoplasma gondii and Neospora spp. among horses in the South of the state of Minas Gerais, Brazil. Braz J Vet Parasito/ 2016; 25(2): 142-150.

Robert-Gangneux F, Dardé ML. Epidemiology of and diagnostic strategies for toxoplasmosis. Clin Microbiol Rev 2012; 25(2): 264296. http://dx.doi.org/10.1128/CMR.05013-11. PMid:22491772.

Santos JPAF, Nasciutti NR, Oliveira PM, Anjos C, Garcia FG, Macêdo AG Jr. Incoordenação de membros posteriores em equinos associados à toxoplasmose - relato de caso. Rev Educ Contin Med Vet Zootec 2014; 12(3): 77.

Shapiro K, Bahia-Oliveira L, Dixon B, Dumètre A, de Wit LA, VanWormer E, et al. Environmental transmission of Toxoplasma gondii: Oocysts in water, soil and food. Food Waterborne Parasitol 2019; 15: e00049.

Silva JCR, Ogassawara S, Adania CH, Ferreira F, Gennari SM, Dubey JP, et al. Seroprevalence of Toxoplasma gondii in captive neotropical felids from Brazil. Vet Parasitol 2001; 102(3): 217-224. http://dx.doi.org/10.1016/S0304-4017(01)00523-4. PMid:11777601.

Stelzer S, Basso W, Benavides Silván J, Ortega-Mora LM, Maksimov P, Gethmann J, et al. Toxoplasma gondii infection and toxoplasmosis in farm animals: risk factors and economic impact. Food Waterborne Parasitol 2019; 15 : e00037.

Tenter AM, Heckeroth AR, Weiss LM. Toxoplasma gondii: from animals to humans. Int J Parasitol 2000; 30(12-13): 1217-1258. http://dx.doi.org/10.1016/S0020-7519(00)00124-7. PMid:11113252.

Valença SRFA, Valença RMB, Pinheiro JW Jr, Albuquerque PPF, Souza OL No, Mota RA. Risk factors for occurrence of antiNeospora spp. antibodies in horses from Alagoas, Brazil. J Equine Vet Sci 2015; 35(11-12): 917-921. http://dx.doi.org/10.1016/j. jevs.2015.08.014.

Venturi SS, Silva AF, Frazão-Teixeira E, Oliveira FCR, Consalter A, Padilha FGF, et al. Characterization of the zoonotic potential of Toxoplasma gondii in horses from Rio de Janeiro State. Acta Trop 2017; 171: 159-162. http://dx.doi.org/10.1016/j. actatropica.2017.03.036. PMid:28377222.

Yang N, Mu MY, Yuan G, Zhang G, Li HK, He JB. Seroprevalence of Toxoplasma gondii in slaughtered horses and donkeys in Liaoning province, northeastern China. Parasit Vectors 2013; 6(1): 140. http://dx.doi.org/10.1186/1756-3305-6-140. PMid:23680297. 